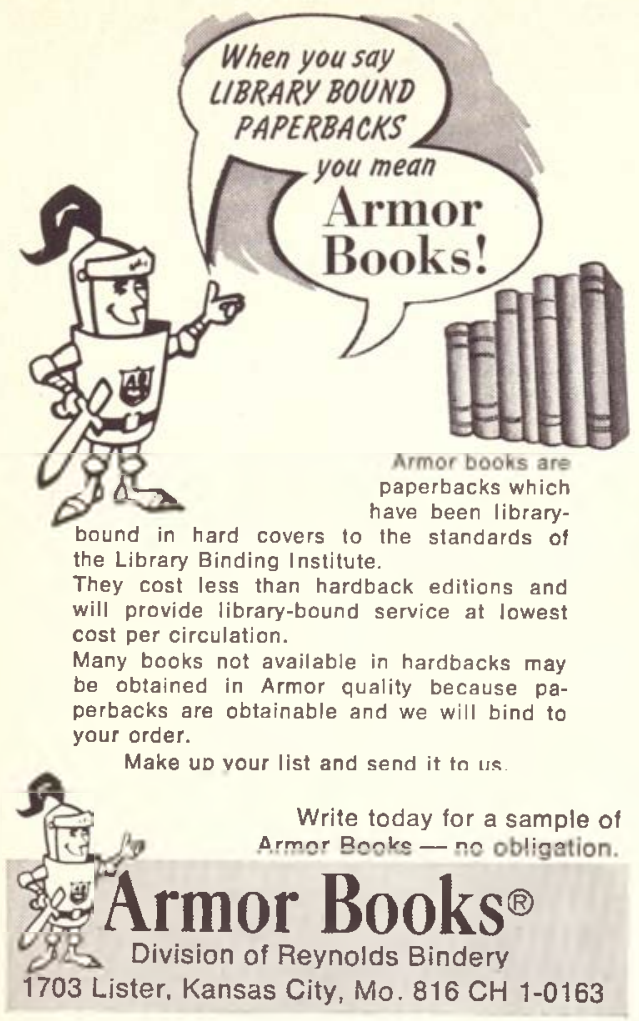

\section{ARE YOU WORKING WITH DISADVANTAGED STUDENTS?}

The College Libraries Section of ACRL is greatly concerned with improving library service to the disadvantaged students on our college campuses. If any college libraries are now significantly involved in working with disadvantaged students, the College Libraries Section would be pleased to hear from you about the program and activities of the College Library on your campus. Please send this information to: JoHN E. Scotr, Chairman, College Libraries Section, West Virginia State College, Institute, West Virginia 25112.

\section{ACRL Membership}

November 30,1969

14,006

November 30,1968

November 30,1967

\section{College Q Research Libraries}

NEWS

News Editor, Michael Herbison, Casper College, Casper, Wyoming 82601 .

Editor, Richard M. Dougherty, University of Colorado Libraries, Boulder, Colorado 80302.

Editorial Board: Richard DeGennaro, Harvard University; Davm Heron, University of Kansas; Elusworth Masos, Hofstra University; Fred Heinhutz, Southern Connecticut State College; WrLlam AxFord, Florida Atlantic University; Peter Hiate, Indiana University.

ACRL Officers, 1969/70: President, Philip J. McNiff; Chairman, College Libraries Section, John E. Scott; Junior College Libraries Section, Ruthe Erickson; Rare Books Section, Robert J. Adelsperger; Subject Specialists Section, Marcia J. Miller; Agriculture and Biological Sciences Subsection, Howard Rovelstad; Art Subsection, Wolfgang M. Freitag; Educational and Bebavioral Science Subsection, Donald Leatherman; Law and Political Science Subsection, Roy M. Mersky; Slavic and East European Subsection, Joseph Placek; University Libraries Section, Roscoe Rouse.

News from the Field, Personnel profiles and notes, classified advertising, official matter of ACRL, and other material of a timely nature is published in the News issues of College \& Research Libraries.

Inclusion of an article or advertisement in $C R L$ does not constitute official endorsement by ACRL or ALA. Production and Advertising and Circulation office: 50 E. Huron St., Chicago, Ill. 60611. Change of address and orders for subscriptions should be addressed to College of Research Libraries, for receipt at the above address, at least two months hefore the publication date of the effective issue.

Subscription to $C R L$ is included in membership dues to ACRL of $\$ 6$ or more; other subscriptions to $C R L$ are $\$ 10$ per year. Neither subscriptions nor memberships include miscellaneous unscheduled supplements, which are available by purchase only. Retroactive subscriptions are not accepted. Single journal copies are available at $\$ 1.50$ each and News issues at $\$ 1.00$ each from ALA Publishing Department.

Indexed in Current Content, Library Literature, and Science Citation Index. Abstracted in Library Science Abstracts. Book reviews indexed in Book Revieu Index. College \& Research Libraries is the official journal of the Association of College and Research Libraries, a division of the American Library Association; and is published seventeen times per year-bi-montbly as a technical journal with 11 monthly News issues, combining July-August-at 1201-05 Bluff St., Fulton, Mo. 65251.

Second-class postage paid at Fulton, Mo. 